\title{
THE EXPOSURE OF HONEY BEES TO PESTICIDE RESIDUES IN THE HIVE ENVIRONMENT WITH REGARD TO WINTER COLONY LOSSES
}

\author{
Krystyna Pohorecka*1 \\ Teresa Szczęsna² \\ Monika Witek ${ }^{2}$ \\ Artur Miszczak ${ }^{3}$ \\ Piotr Sikorski ${ }^{3}$ \\ ${ }^{1}$ National Veterinary Research Institute, Department of Honeybee Diseases, \\ Puławy, Poland \\ ${ }^{2}$ Research Institute of Horticulture, Apiculture Department, Puławy, Poland \\ ${ }^{3}$ Research Institute of Horticulture, Food Safety Laboratory, Skierniewice, Poland \\ *corresponding author: krystyna.pohorecka@piwet.pulawy.pl \\ Received: 10 January 2017; Accepted: 25 May 2017
}

\section{Abstract}

The present studies are the second part of the research project dedicated to finding the causes for increased winter mortality of honey bee colonies. The aim of this task was to investigate incidents of overwintered colonies' death with regard to the potential interrelation to the exposure to pesticides. The samples of winter stores of bee bread and sugar food (honey or syrup processed by bees), beeswax and bees collected from apiaries with low and high rates of winter colony mortality were searched for acaricides used to control $V$. destructor and plant protection pesticides. The presence of acaricides used in apiculture has been detected in the $51 \%$ beeswax samples. The most abundant acaricide was tau-fluvalinate. The stores of bee bread and sugar food had a similar frequency of plant protection pesticide occurrence, ranging between $50-60 \%$, but the number of active substances and their concentrations were substantially lower in sugar food samples. The most prevalent pesticides in pollen were fungicides (carbendazim and boscalid) and insecticides (acetamiprid and thiacloprid). Only a few pesticides were found in the several dead honey bees. The level of pesticide contamination (frequency, concentration, toxicity) of hive products and bees originating from apiaries with both a high and low winter colony survival rates, was similar, which created a similar extent of risk. Although the multiple varroacides and pesticides were present in the hive environment we not found unequivocal links between their residues and high winter colony mortality.

Keywords: bee bread, beeswax, honey bees, honey/syrup stores, pesticide residues, winter honey bee colony losses

\section{INTRODUCTION}

The widespread use of pesticides in crop protection management is indicated as one of the greatest hazards to bee health (Johnson et al., 2010; Goulson, 2013). Exposure to pesticides has received significant attention on account of the depopulation of honey bee colonies (Apis mellifera L.) persisting for several last years in many regions of the world (van der Zee et al., 2012). Honey bees are directly exposed to the plant protection products at the time of spraying, through pollen, and nectar collection and storage in the hive. The surface water and guttation water produced by plants are also regarded as potential sources of pesticides (Johnson, 2015). Another cause of the pesticide presence in hives are acaricides commonly used in apiculture to control the parasitic mite Varroa destructor. These compounds are the main source of contamination of beeswax (Wallner, 1999; Mullin et al., 2010). The toxic effect of pesticides depends on their chemical properties, dose, route, time of exposure as well as the state of the bees (Smirle \& Winston, 1987; Wahl \& Ulm, 1983).

The most hazardous pesticide to bees are insecticides compounds (I), especially those of 
the neonicotinoid, pyrethrin and organophosphate classes. Herbicides $(H)$ and fungicides $(F)$, which are not dedicated to combating insects, have a generally low acute toxicity to adult bees (Johnson, 2015). After insecticides, fungicides are the second group of pesticides that are most detected in honey bee colonies (Mullin et al., 2010), although their toxic effect is more frequently observed in bee larvae than in adults (Zhu et al., 2014).

A pesticide dose that kills $50 \%$ of exposed bees in a short time $(24,48$ or $96 \mathrm{~h})$ is the measure of their acute toxicity $\left(L_{50}\right)$. Sublethal doses are also significant to the behavior, physiology and health of individual bees (Desneux et al., 2007). However, it is more difficult to prove the effects of sublethal amounts on honey bee colony (Berry et al., 2013). Chronic contact and dietary exposure to multi-residues in pollen, honey and beeswax at the same time significantly threatens honey bee colonies. Pesticide mixtures may entail an synergistic effect and unexpected increase in toxicity in comparison to the simple sum of individual active substance toxicity (Pilling \& Jepson, 1993; Mullin et al., 2010).

The presented study has been carried out as a part of a four-year research project that started after the survival of overwintered honey bee colonies significantly declined in Poland. The purpose of this project was to define which factors are responsible for the occurrence of this phenomenon in national apiaries. In 2009-2012 approximately 500 apiaries with a rate from 0 to $100 \%$ of winter losses of honey bees were sampled for bees and hive products. Collected data in the part about the natural food resources, bee management techniques and epidemiological status of pathogens and parasites and correlation of these factors with colony mortality over the winter has been described in Pohorecka et al. (2014). Results of the evaluation of honey bee colonies exposed to an environment contaminated with plant protection pesticides (PPP) and apiculture acaricides in relation to colony mortality are presented in this paper.

\section{MATERIAL AND METHODS}

The presented research was carried out in cooperation with beekeepers who voluntarily took part in the project. The participants had come from all of Poland's sixteen voivodeships; most had observed an increased rate in colony loss during winter but some had not experienced this problem at all. Beekeepers were instructed about the type and quantity of diagnostic material to be collected and the methods of sampling. The bee hive environment was assessed in the same colonies in which pathogen and parasite loads were measured (Pohorecka et al., 2014).

The majority of samples were collected in the early spring during the first inspection of colonies after the winter. In each apiary all types of samples were separately gathered from the same randomly selected dead colonies. If less than ten colonies died in the apiary, all sample types were taken from all colonies. If ten or more colonies died in the apiary, samples were taken from ten colonies. In the apiaries where all colonies survived the winter, up to ten samples were taken from living honey bee colonies. The following types of material were collected from each selected beehive: a minimum $150 \mathrm{ml}$ of winter stores of sugar food (honey or syrup processed by bees) from brood combs (gathered into containers, in case whole combs with stores were sent, the sugar food was extracted in laboratory), piece of comb with a minimum 100 cells of bee bread, piece of empty brood comb (approx. 10x10 cm), and a minimum 300 dead of worker bees from the bottom board. In the laboratory, individual types of samples from each apiary were pooled and analyses were performed on bulk samples for each matrix. Beeswax samples were analyzed for the presence of acaricides used to control $V$. destructor. The bee bread, sugar food and honey bee samples were analyzed for pesticide residues from plant protection products. All the samples were stored at $-20^{\circ} \mathrm{C}$ until analysis.

\section{Acaricide analysis}

\section{Reagents and chemicals}

Amitraz is an unstable molecule and degrades into three metabolites: $N$-(2,4-dimethylphenyl)- 
$N$-methylformamidine (DPMF), 2,4-dimethyl formanilide (DMF), and 2,4-dimethylaniline (DMA). DMF as the principal degradation product left in pure wax (Korta et al., 2001; Korta et al., 2003) was monitored for the presence of amitraz in the beeswax samples. Most of the referenced standard ingredients were purchased from commercial suppliers. Certified acaricide standards of DMF, coumaphos, taufluvalinate, bromopropylate, acrinathrine, bromfenvinfos were purchased from Dr. Ehrenstorfer (Augsburg, Germany). All working standard solutions were prepared by dissolving each compound in acetone at a concentration of $1000 \mathrm{mg} / \mathrm{l}$ and stored at $-21^{\circ} \mathrm{C}$. These reference materials were used for the preparation of beeswax samples fortified with known quantities of analyzed substances. Isooctane were supplied by SIGMA-ALDRICH Co. (St. Louis, MO, USA) and other chemicals - acetone, hexane - by Merck (Darmstadt, Germany).

\section{Beeswax sample preparation}

Analysis of acaricide residues was performed on bulk samples of beeswax formed after the melting of all sections of the combs collected from one apiary. This procedure was based on techniques developed by Jimenez et al. (2005) and Adamczyk et al. (2007). The pieces of combs were cut, placed into a 1L-glass jar and soaked for about 30 min in distilled water (about $500 \mathrm{ml}$ ) at $60^{\circ} \mathrm{C}$. During the step of soaking, the mixture was vigorously stirred. Afterwards, the pieces of combs were placed in a colander and washed with about $1 \mathrm{~L}$ of distilled water. Next, all the washed sections were placed on a gauze spread over a beaker with water and ovenmelted at $80^{\circ} \mathrm{C}\left( \pm 5^{\circ} \mathrm{C}\right)$ for $30 \mathrm{~min}$. The mixture was cooled at room temperature so that the beeswax could solidify on the water. Purified wax samples were dried in the laboratory at a temperature of $20-25^{\circ} \mathrm{C}$ and stored at this temperature until analysis.

Beeswax foundation produced for organic beekeeping (Fachverband Bienenzuchtausrüstung, Gewähr für reines Bienenwachs 1566) was used for the method development and validation. The samples of beeswax foundation were spiked at concentration levels of 0.01 ,
$0.05,0.1,0.5,1.0,5.0$ and $10.0 \mathrm{mg} / \mathrm{kg}$ for each of the analyte. Beeswax foundation samples were weighed in glass jars/beakers and melted at $70^{\circ} \mathrm{C}$ using a thermostated mechanical shaker (Innova), after which acetone standard solutions of analytes were added. The mixtures were strongly mixed until the acetone was evaporated. The spiked beeswax samples were kept at room temperature until analysis, away from direct sunlight.

\section{Extraction of analytes}

The SPE technique developed by Adamczyk et al. (2007) was adopted for acaricide residue extraction from beeswax samples. A beeswax sample of $0.2 \mathrm{~g}$ was weighed in a polypropylene copolymer (PPCO) tube to which $10 \mu$ of internal standard solution (bromfenvinfos $10 \mathrm{ng} / \mathrm{\mu l}$ ) and $10 \mathrm{ml}$ of isooctane were added. The beeswax sample was completely dissolved at $70^{\circ} \mathrm{C}$ within 5 min using a Reacti-Therm III Heating/Stirring Module. The solution was transferred to the freezer for two hours, and then centrifuged for $15 \mathrm{~min}$ at $-10^{\circ} \mathrm{C}$ and the liquid phase was decanted into a new tube. After that, $6 \mathrm{ml}$ of isooctane was added to the sediment and the extracting procedure was repeated twice for each sample. Three extracts per sample were collected into the same tube and passed through Clearnet Florisil-SPE $1000 \mathrm{mg} / 6 \mathrm{ml}$ Column (Agela Technologies) for acaricide residue extraction from the beeswax matrix. The eluate was evaporated to dryness in the Pierce Reacti$V_{a P^{T M}}$ III under nitrogen, then dissolved in $1 \mathrm{ml}$ of isooctane and filtered through $0.2 \mu \mathrm{m}$ PTFE syringe filter into an autosampler vial.

\section{GC-ECD analysis}

The GC-ECD procedure for acaricide residue analysis in beeswax samples was adopted from Fries et al. (1998) and Bogdanov et al. (2003). The analysis were performed with Gas Chromatograph with an Electron-Capture detector (ECD) (GC-14A, Shimadzu) and DB-35MS $30 \mathrm{~m}$ $\times 0.25 \mathrm{~mm} \times 0.25 \mu \mathrm{m}$ (Agilent J\&W) chromatographic column. The oven temperature was programmed for $120^{\circ} \mathrm{C}$ ramped at $8^{\circ} \mathrm{C} / \mathrm{min}$ to $250^{\circ} \mathrm{C}$ and held for $3 \mathrm{~min}$, and then ramped again at $3^{\circ} \mathrm{C} / \mathrm{min}$ to $310^{\circ} \mathrm{C}$ and held for 8 min. Injector and detector temperatures were $240^{\circ} \mathrm{C}$ and 
Limit of detection (LOD), limit of quantification (LOQ) and working range of acaricide analytical procedure in beeswax

\begin{tabular}{|c|c|c|c|c|c|}
\hline \multirow[t]{2}{*}{ Analyte } & \multirow{2}{*}{$\begin{array}{l}\text { LOD (mg/ } \\
\text { kg) }\end{array}$} & \multirow{2}{*}{$\begin{array}{l}\text { LOQ (mg/ } \\
\text { kg) }\end{array}$} & \multirow{2}{*}{$\begin{array}{l}\text { Working range } \\
\quad(\mathrm{mg} / \mathrm{kg})\end{array}$} & \multicolumn{2}{|c|}{$\begin{array}{c}\text { Linearity } \\
\text { (correlation coefficient) }\end{array}$} \\
\hline & & & & from - to & mean \\
\hline Acrinathrin & 0.10 & 0.50 & $0.50-10.00$ & $0.9956-0.9972$ & 0.9960 \\
\hline Вromopropylate & 0.10 & 0.50 & $0.50-10.00$ & $0.9974-0.9980$ & 0.9973 \\
\hline Coumaphos & 0.10 & 0.50 & $0.50-10.00$ & $0.9958-0.9976$ & 0.9969 \\
\hline DMF & 0.01 & 0.05 & $0.05-5.00$ & $0.9952-0.9986$ & 0.9975 \\
\hline Flumethrin & 0.50 & 1.00 & $1.00-10.00$ & $0.9952-0.9972$ & 0.9965 \\
\hline Tau-fluvalinate & 0.10 & 0.50 & $0.50-10.00$ & $0.9959-0.9984$ & 0.9972 \\
\hline
\end{tabular}

$340^{\circ} \mathrm{C}$, respectively. A split/splitless injector was used in the split mode with a split ratio of 1:11 and $1 \mu$ of extract was injected on the column. The carrier gas was helium with a constant flow rate of $1 \mathrm{ml} / \mathrm{min}$. The fortified beeswax samples were used for the system calibration with the following levels of each analyzed substance: $0.01,0.05,0.1,0.5,1.5$ and $10 \mathrm{mg} / \mathrm{kg}$. The internal standard method with bromfenvinfos was used for calculation of analyzed acaricide residues in the beeswax.

\section{GC-MS analysis}

DMFs were determined using the GC/MS technique on a Gas Chromatograph Mass Spectrometer (GCMS-QP 2010 Plus, Shimadzu) and ZB-5HT INFERNO $20 \mathrm{~m} \times 0.18 \mathrm{~mm} \times 0.18 \mu \mathrm{m}$ chromatographic column (Phenomenex) (Lodesani et al., 2008). Separation and quantity determination of DMF were received for the following oven temperature program: $60^{\circ} \mathrm{C}$ for 1 min ramped at $20^{\circ} \mathrm{C} / \mathrm{min}$ to $260^{\circ} \mathrm{C}$ and held for $5 \mathrm{~min}$, and then ramped again at $30^{\circ} \mathrm{C} / \mathrm{min}$ to $340^{\circ} \mathrm{C}$ and held for 30 min, injector temperature $250^{\circ} \mathrm{C}$, and ion source and interface temperatures $250^{\circ} \mathrm{C}$ and $348^{\circ} \mathrm{C}$, respectively. A split/splitless injector was used in the splitless mode $(t=1 \mathrm{~min})$ and $1 \mu$ of the extract was injected on the column. The carrier gas was helium with a constant flow of $0.43 \mathrm{ml} / \mathrm{min}$. The DMF was identified out with full SCAN mode (50-650 Mz), and quantifed with SIM (selected ion monitoring). The quantification and qualification mass ions for DMF were 120 and 149, respectively. The external standard method was utilised to quantify $h$ the fortified samples of beeswax at concentrations of 0.01 , $0.05,0.1,0.5,1.0,5.0$, and $10.0 \mathrm{mg} / \mathrm{kg}$.

\section{Validation parameters}

The validation parameters - detection and quantification limits, working range and linearity are summarized in Tab. 1. The quantification limit of DMF residues was calculated on a level of $0.05 \mathrm{mg} / \mathrm{kg}, 1 \mathrm{mg} / \mathrm{kg}$ for flumethrin, and $0.5 \mathrm{mg} / \mathrm{kg}$ for coumaphos, bromopropylate, acrinathrin, fluvalinate and deltamethrin. The ECD detector response of coumaphos, bromopropylate, acrinathrin, fluvalinate and deltamethrin residue determination in beeswax was linear in the concentration range of $0.5-10 \mathrm{mg} / \mathrm{kg}$, and for flumethrin $1.0-10 \mathrm{mg} / \mathrm{kg}$. The MS detector response of DMF was linear in the concentration range of $0.05-5 \mathrm{mg} / \mathrm{kg}$.

The correlation coefficient of linear dependence of acaricide residue concentration and peak area in the working range reached a value of over 0.995 for all analyzed substances. The recovery of analyzed substances ranged from 60.2 (for DMF) to $96.0 \%$ (for coumaphos), $87.7 \%$ on average. The coefficient of variation of the repeatability and the within-laboratory reproducibility of the elaborated methods did not exceed $20 \%$ thus demonstrating the methods' sufficient accuracy and precision.

\section{Pesticide analysis \\ Reagents and chemicals}

The 80 pesticides analyzed in the multi-residue method are listed in Tab. 2. All pesticide standards had purity $\geq 93.3 \%$ (typically > 99\%) and were purchased from Fluka, Sigma-Aldrich, 
Table 2

A list of analyzed pesticides, method performance and limit of detection

\begin{tabular}{|c|c|c|c|c|c|c|c|}
\hline \multirow{2}{*}{ Compound } & \multirow{2}{*}{$\mathrm{RT}$ (min) } & \multirow{2}{*}{$\begin{array}{c}\text { Fragmentor } \\
\text { voltage }\end{array}$} & \multirow{2}{*}{$\begin{array}{l}\text { MRM Transition } \\
\text { (m/z) }\end{array}$} & \multirow{2}{*}{$\begin{array}{c}\text { Collision } \\
\text { energy (eV) }\end{array}$} & \multicolumn{3}{|c|}{ LOD* (ng/g) } \\
\hline & & & & & Nectar & Pollen & Bees \\
\hline Acephate & 0.87 & 60 & $184.0->143.0$ & 4 & 5 & 10 & 5.0 \\
\hline Acetamiprid & 4.60 & 80 & 223.1 -> 126.0 & 20 & 0.1 & 0.2 & 0.3 \\
\hline Aldicarb & 6.90 & 80 & $116.0->70.1$ & 4 & 2 & 5 & 2.0 \\
\hline Aldicarb-sulfone & 1.50 & 80 & 223.1 -> 86.1 & 8 & 5 & 10 & 2.0 \\
\hline Aldicarb-sulfoxide & 1.10 & 70 & 207.1 -> 89.0 & 8 & 4 & 6 & 4.0 \\
\hline Azoxystrobin & 13.00 & 120 & 404.1 -> 372.1 & 10 & 0.4 & 1 & 0.4 \\
\hline Boscalid & 13.21 & 130 & $343.0->271.1$ & 35 & 4 & 10 & 4.0 \\
\hline Bromuconazole & 12.62 & 150 & 378.0 -> 158.9 & 29 & 4 & 9 & 4.0 \\
\hline Captan & 5.56 & 80 & 225.1 -> 86.5 & 8 & 1 & 2 & 1 \\
\hline Carbaryl & 9.77 & 80 & 202.1 -> 145.1 & 4 & 1 & 2 & 1.0 \\
\hline Carbendazim & 2.66 & 96 & 192.1 -> 160.0 & 17 & 0.1 & 0.3 & 0.5 \\
\hline Carbofuran & 9.23 & 80 & 222.1 -> 123.0 & 21 & 0.2 & 0.5 & 0.2 \\
\hline $\begin{array}{c}\text { Carbofuran-3-hy- } \\
\text { droxy }\end{array}$ & 3.34 & 90 & 238.1 -> 163.0 & 12 & 0.6 & 3 & 0.6 \\
\hline Carbofuran-3-keto & 7.15 & 80 & 236.1 -> 179.0 & 9 & 3 & 5 & 3.0 \\
\hline Chloridazon & 3.53 & 145 & $222.0->77.0$ & 35 & 0.2 & 3 & 0.2 \\
\hline Chlorotoluron & 9.63 & 120 & $213.1->72.0$ & 33 & 0.5 & 1 & 0.5 \\
\hline Clothianidin & 3.07 & 104 & 250.1 -> 132.0 & 16 & 0.5 & 1 & 2.0 \\
\hline Cymoxanil & 5.72 & 50 & 199.0 -> 128.0 & 4 & 1 & 3 & 1.0 \\
\hline Cyproconazole & 12.25 & 120 & 292.1 -> 70.0 & 15 & 0.8 & 2 & 0.8 \\
\hline Desmedipham & 12.19 & 84 & 318.1 -> 136.0 & 26 & 0.1 & 0.3 & 0.1 \\
\hline Diethofencarb & 12.51 & 85 & 268.1 -> 124.0 & 30 & 0.5 & 2 & 0.5 \\
\hline Dimethoate & 4.08 & 70 & 230.1 -> 199.0 & 4 & 0.5 & 1 & 0.5 \\
\hline Fenbuconazole & 13.69 & 120 & 337.1 -> 70.0 & 20 & 0.9 & 5 & 0.9 \\
\hline Fenpropimorph & 13.19 & 130 & $304.3->146.9$ & 30 & 0.1 & 0.4 & 0.1 \\
\hline Fenpyroximate & 18.33 & 130 & 422.2 -> 138.0 & 33 & 0.8 & 1 & 0.8 \\
\hline Flonicamid & 2.40 & 90 & 230.1 -> 174.0 & 16 & 5 & 8 & 5.0 \\
\hline Fluquinconazole & 13.26 & 100 & 376.0 -> 307.0 & 20 & 3 & 4 & 3.0 \\
\hline Flurochloridon & 14.11 & 100 & 312.1 -> 292.0 & 29 & 5 & 10 & 5.0 \\
\hline Flutriafol & 10.10 & 120 & 302.1 -> 70.0 & 15 & 0.5 & 1.5 & 0.5 \\
\hline Formetanate & 0.87 & 120 & 222.1 -> 165.1 & 12 & 1 & 2 & 1.0 \\
\hline Hexythiazox & 18.00 & 128 & 353.1 -> 168.1 & 25 & 0.7 & 3 & 0.7 \\
\hline Imazalil & 10.28 & 130 & 297.0 -> 158.9 & 22 & 0.4 & 1 & 0.4 \\
\hline Imidacloprid & 3.63 & 80 & 256.1 -> 175.0 & 21 & 0.2 & 0.8 & 0.5 \\
\hline Indoxacarb & 16.55 & 104 & 528.1 -> 203.0 & 45 & 2 & 4 & 2.0 \\
\hline Lenacil & 8.84 & 70 & 235.1 -> 153.0 & 13 & 0.5 & 1 & 0.5 \\
\hline Linuron & 12.25 & 110 & $249.0->132.9$ & 30 & 2 & 3 & 2.0 \\
\hline Malaoxon & 9.28 & 90 & 315.1 -> 99.0 & 25 & 0.2 & 0.5 & 0.2 \\
\hline Malathion & 13.89 & 80 & 331.0 -> 99.0 & 21 & 0.3 & 0.5 & 0.3 \\
\hline Metalaxyl & 10.45 & 90 & 280.2 -> 220.1 & 9 & 0.2 & 0.4 & 0.2 \\
\hline Metamitron & 3.05 & 110 & 203.1 -> 175.0 & 13 & 1 & 2 & 1.0 \\
\hline Metconazole & 14.00 & 120 & $320.2->70.0$ & 25 & 0.7 & 2 & 0.7 \\
\hline Methamidophos & 0.86 & 90 & $142.0->94.0$ & 9 & 1 & 5 & 1.0 \\
\hline Methiocarb & 12.51 & 130 & 226.1 -> 124.0 & 25 & 0.4 & 1 & 0.4 \\
\hline Methiocarb sulfoxide & 2.73 & 80 & 242.1 -> 185.0 & 10 & 0.2 & 0.5 & 0.2 \\
\hline Methiocarb-sulfone & 5.91 & 70 & 258.1 -> 122.0 & 16 & 5 & 9 & 5.0 \\
\hline Methomyl & 1.84 & 70 & 163.1 -> 88.0 & 8 & 0.4 & 1 & 0.4 \\
\hline Methoxyfenozide & 13.77 & 90 & 369.2 -> 91.0 & 45 & 0.1 & 0.2 & 0.1 \\
\hline Monocrotophos & 1.44 & 60 & $224.0->127.0$ & 12 & 2 & 3 & 2.0 \\
\hline
\end{tabular}




\begin{tabular}{|c|c|c|c|c|c|c|c|}
\hline Myclobutanil & 12.82 & 115 & 289.1 -> 125.0 & 37 & 5 & 10 & 5.0 \\
\hline Napropamide & 13.47 & 108 & 272.1 -> 129.1 & 14 & 0.5 & 1 & 0.5 \\
\hline Omethoate & 0.89 & 90 & $214.0->125.0$ & 20 & 1 & 1.5 & 1.0 \\
\hline Oxadixyl & 8.07 & 80 & 279.1 -> 219.1 & 9 & 0.3 & 1 & 0.3 \\
\hline Oxamyl & 1.53 & 85 & 237.1 -> 72.0 & 10 & 0.2 & 0.6 & 0.2 \\
\hline Paclobutrazol & 11.98 & 120 & 294.1 -> 70.1 & 20 & 1 & 2 & 1.0 \\
\hline Рагаохоn (ethyl) & 10.75 & 90 & $276.0->219.9$ & 9 & 0.4 & 0.9 & 0.4 \\
\hline Рагаoxon-methyl & 7.99 & 130 & 248.0 -> 201.9 & 18 & 1 & 2 & 1.0 \\
\hline Parathion & 15.23 & 90 & 292.1 -> 235.9 & 8 & 5 & 10 & 5.0 \\
\hline Pencycuron & 15.99 & 128 & 329.1 -> 125.0 & 25 & 0.1 & 0.3 & 0.1 \\
\hline Pendimethalin & 17.91 & 80 & $282.1->212.0$ & 9 & 0.9 & 3 & 0.9 \\
\hline Phenmedipham & 12.18 & 84 & 301.1 -> 136.0 & 18 & 2 & 4 & 2.0 \\
\hline Ргоchloraz & 14.35 & 90 & 376.0 -> 308.0 & 9 & 0.6 & 1 & 0.6 \\
\hline Propamocarb & 1.13 & 100 & $189.2->102.0$ & 13 & 1.1 & 2 & 1.1 \\
\hline Propaquizafop & 17.02 & 120 & 444.1 -> 100.1 & 14 & 0.5 & 1 & 0.5 \\
\hline Pyridaben & 19.36 & 110 & $365.2->147.1$ & 25 & 0.1 & 0.2 & 0.1 \\
\hline Quizalofop-ethyl & 16.73 & 120 & $373.0->299.0$ & 18 & 0.1 & 0.3 & 0.1 \\
\hline Rimsulfuron & 9.29 & 124 & 432.1 -> 182.0 & 21 & 4 & 10 & 4.0 \\
\hline Spinosyn A & 14.15 & 140 & 732.5 -> 142.1 & 35 & 0.4 & 1 & 0.4 \\
\hline Spinosyn D & 15.00 & 120 & 746.5 -> 142.1 & 15 & 1 & 2 & 1.0 \\
\hline Spirodiclofen & 19.58 & 90 & $411.1 \rightarrow 71.1$ & 13 & 0.5 & 0.8 & 0.5 \\
\hline Spiroxamine & 11.54 & 120 & $298.3->144.1$ & 18 & 0.1 & 0.2 & 0.1 \\
\hline Tebuconazole & 13.48 & 120 & 308.1 -> 70.1 & 22 & 0.5 & 5 & 1.0 \\
\hline Tebufenpyгad & 16.84 & 155 & $334.2 \rightarrow 144.9$ & 26 & 1 & 4 & 1.0 \\
\hline Thiabendazole & 3.50 & 120 & $202.0->175.0$ & 25 & 0.1 & 0.4 & 0.1 \\
\hline Thiacloprid & 6.75 & 90 & $253.0->126.0$ & 20 & 0.1 & 0.4 & 0.1 \\
\hline Thiametoxam & 2.23 & 80 & $292.0->211.0$ & 9 & 0.1 & 0.3 & 1.0 \\
\hline Thiodicarb & 9.43 & 84 & $355.0->88.0$ & 12 & 0.5 & 4 & 0.5 \\
\hline Thiophanate-methyl & 8.86 & 100 & 343.1 -> 151.0 & 20 & 0.6 & 2 & 0.6 \\
\hline Triadimefon & 13.07 & 120 & $294.1 \rightarrow 69.0$ & 20 & 5 & 10 & 5.0 \\
\hline Triadimenol & 11.98 & 90 & 296.1 -> 70.1 & 16 & 4 & 10 & 4.0 \\
\hline Triticonazole & 12.36 & 115 & 318.1 -> 125.0 & 38 & 5 & 5 & 5.0 \\
\hline Zoxamide & 15.44 & 116 & $336.0 \rightarrow 159.0$ & 45 & 0.5 & 1 & 0.5 \\
\hline
\end{tabular}

*LOD - limit of detection

Promochem (Institute of Industrial Organic Chemistry), Dr Ehrenstorfer, Riedel-de Haen and Supelco. Ultra gradient HPLC were purchased from Carlo Erba. Anhydrous magnesium sulfate (grit and powder), sodium choride, sodium citrate tribasic and sodium hydrogencitrate sesquihydrate were ordered from Sigma-Aldrich. Acetic acid (HOAc) (98\% purity), n-heksan (99\% purity) were obtained from Chempur. Formic acid ( $98 \%$ purity) was purchased from J.T. Baker, and ammonium formate from Fluka. Both SPE sorbents PSA bonded (primary secondary amine) and Discovery DSC-18 were obtained from Supelco. Triphenylphosphate (TPP) and Tri (2,3-dichloropropyl) phosphate (TDCPP) were purchased from Fluka.

Individual standard stock solutions at $1000 \mu \mathrm{g} / \mathrm{ml}$ were prepared through the dissolving of standards in acetonitrile, methanol or acetone, depending on the solubility of a particular pesticide, and were stored in amber glass flasks at $-18^{\circ} \mathrm{C}$. A working standard pesticide mixture at a concentration of $10 \mu \mathrm{g} / \mathrm{ml}$ in MeCN (acidified with $0.1 \% \mathrm{HOA} c(\mathrm{v} / \mathrm{v}))$ was prepared from the stock solutions and kept at $4^{\circ} \mathrm{C}$ before use. This mixture was appropriately diluted in MeCN for the preparation of matrix-matched calibration and fortification standards. TPP was prepared at $0.5 \mu \mathrm{g} / \mathrm{ml}$ in MeCN (acidified 0.1\% HOAC $(\mathrm{v} / \mathrm{v}))$, and added to the final extracts, blanks and matrix-matched calibration. A solution of $50 \mu \mathrm{g} / \mathrm{ml}$ TDCPP in MeCN (surrogate standard) was added throughout the entire procedure and was used to control the extraction step. 


\section{Sugar food, bee bread and honey bee samples preparation}

The sample preparation procedure based on a modified QuEChERS (Quick Easy Cheap Effective Rugged Safe) (Anastassiades et al., 2003; Wiest et al., 2011) has been described in detail in a study by Pohorecka et al. (2012). In brief, the matrix (sugar food $10 \mathrm{~g}$, bee bread, honey bees $5 \mathrm{~g}$ each) was vortex with TDCPP, deionised water, acetonitrile and n-hexane. The mixture was then mixed and centrifuged with $\mathrm{MgSO}_{4^{\prime}}$ $\mathrm{NaCl}$, sodium citrate tribasic, sodium hydrogencitrate sesquihydrate. MeCN supernatant was mixed and centrifuged with $\mathrm{MgSO}_{4^{\prime}}$ PSA and C18. The obtained extract, after being mixed with water, acetonitrile and internal standard TPP, and then after being filtered, was analyzed by LC/MS/MS.

\section{LC-MS analysis}

For the LC analysis, an Agilent $1200 \mathrm{HPLC}$ system with a binary pump was used. The analytes were separated on the C18 analytical column of 100 $\mathrm{mm} \times 2.1 \mathrm{~mm}$ and $1.8 \mathrm{um}$ particle size (Agilent Zorbax Eclipse Plus). For the mass spectrometric analysis, an Agilent 6410 Triple-Quad LC/MS system was applied. The data recorded was processed with the Mass Hunter software. Both processes were conducted under previously described conditions (Pohorecka et al., 2012).

\section{Validation parameters}

The method was prepared according to the requirements of guideline SANCO/825/00 rev 8.1 from 16.11.2010: "Guidance document of pesticide residue analytical methods". Mean recovery efficiencies for all bee collected matrices ranged between $70-110 \%$ and the relative standard deviation was less than $20 \%$, thus demonstrating the sufficient accuracy and precision of the method. The LODs were estimated from the injection of matrix-matched solutions at concentration levels corresponding to a signal-to-noise ratio of about 3 for the quantitation ion and presence of the confirmatory ion as well. The LOD levels for nectar and pollen samples are included in Tab. 2. During validation, linearity of the method was evaluated in matrixmatched standards for each matrix. The calibration were found to be linear with correlation coefficients greater than 0.99 for pesticides included in the method.

\section{Statistical analyses}

All the statistical analyses were carried out using Statistica 10 StatSoft'. The values obtained for the investigated parameters were compared between the group of apiaries with high losses (>10\%) of bee colonies and group of apiaries with low losses $(\leq 10 \%)$ of bee colonies. The relationships between the investigated qualitative characteristics were evaluated with the Chi-square test. P-values $\leq 0.05$ were considered significant. Due to a lack of a normal distribution of variables the Mann-Whitney $U$ test was used for comparison of pesticide concentrations.

\section{RESULTS}

A total of 727 samples of honey bees, food stores and beeswax were analyzed for pesticide residues. Various compounds were found to be present in $44.3 \%$ of samples. The prevalence of pesticides in bee bread, sugar food and beeswax was similar ranging from 49.6 to $60.2 \%$ (Fig. 1), while in honey bees this did not exceed $13.5 \%$.

\section{Acaricide residues in beeswax}

Acaricides used in apiculture were detected in 156 of 306 beeswax samples analyzed. The most frequent residue was tau-fluvalinate found in $39.9 \%$ of samples (Tab. 3). The positive samples contained on average $1.6 \mathrm{mg} / \mathrm{kg}$ of this compound, wherein a mean concentration of tau-fluvalinate has been exceeded in one third of samples. Coumaphos residues were found in the second highest frequency $(14.7 \%$ of polluted samples) with a mean concentration of about $1.0 \mathrm{mg} / \mathrm{kg}$. Only five samples contained coumaphos in quantities higher than the average. Detection of other pesticides ranged from $1.0 \%$ (acrinathrin) to 3.3\% (amitraz as DMF). All samples were found to have no flumethrin residues.

There were no significant differences in the level of beeswax contamination recorded between the apiaries with high and low winter colony losses. Both frequency of detection (Fig.2) and amounts of all acaricides searched were approximated. Mean concentrations of taufluvalinate were 1.59 (sd \pm 0.53 ) and $1.61 \mathrm{mg} / \mathrm{kg}$ 
Acaricide residues in beeswax samples $(n=306)$

Table 3

\begin{tabular}{ccccccc}
\hline \multirow{2}{*}{ Acaricide } & $\begin{array}{c}\text { Number } \\
\text { of positive samples }\end{array}$ & $\begin{array}{c}\text { Proportion } \\
\text { of positive samples } \\
(\%)\end{array}$ & \multicolumn{2}{c}{$\begin{array}{c}\text { Concentration } \\
(\mathrm{mg} / \mathrm{kg})\end{array}$} & LoQ* \\
\cline { 4 - 5 } & & 1.0 & 5.14 & 10.97 & 0.5 \\
Acrinathrin & 3 & 2.6 & 0.99 & 2.28 & 0.5 \\
Bromopropylate & 8 & 14.7 & 0.99 & 11.02 & 0.5 \\
Coumaphos & 45 & 3.3 & 0.18 & 0.27 & 0.05 \\
DMF (amitraz) & 10 & nd & nd & nd & 1.0 \\
metabolite) & & nd & 39.9 & 1.60 & 8.10 & 0.5 \\
Flumethrin & 122 & & & & \\
Tau-fluvalinate & & &
\end{tabular}

*LOQ - limit of quantification

nd $=$ not detected

(sd \pm 1.47 ) in beeswax from apiaries with low and high rates of colony mortality, respectively (Mann-Whitney U test, $\mathrm{p}=0.138$ ). Coumaphos measured in the beeswax from these apiaries had mean concentrations of 0.71 (sd \pm 0.09 ) and $1.05 \mathrm{mg} / \mathrm{kg}$ (sd \pm 1.84 ), respectively (MannWhitney $\mathrm{U}$ test, $\mathrm{p}=0.342$ ). Multiple residues (more than one acaricide) were found in $7.0 \%$ and $8.1 \%$ of beeswax samples, respectively.
Plant protection pesticide residues in winter food stores and honey bees

A total of 123 samples of bee bread were analyzed, $60.2 \%$ of which were found to be contaminated. The most frequently detected residues were from fungicides (in $45.3 \%$ samples) followed in order from insecticides (32.0\%) and herbicides (24.5\%). In positive bee bread samples, 22 pesticides were noted: ten fungicides, eight insecticides and four herbicides (Tab. 4). At least

\section{- Positive samples $\square$ Negative samples}

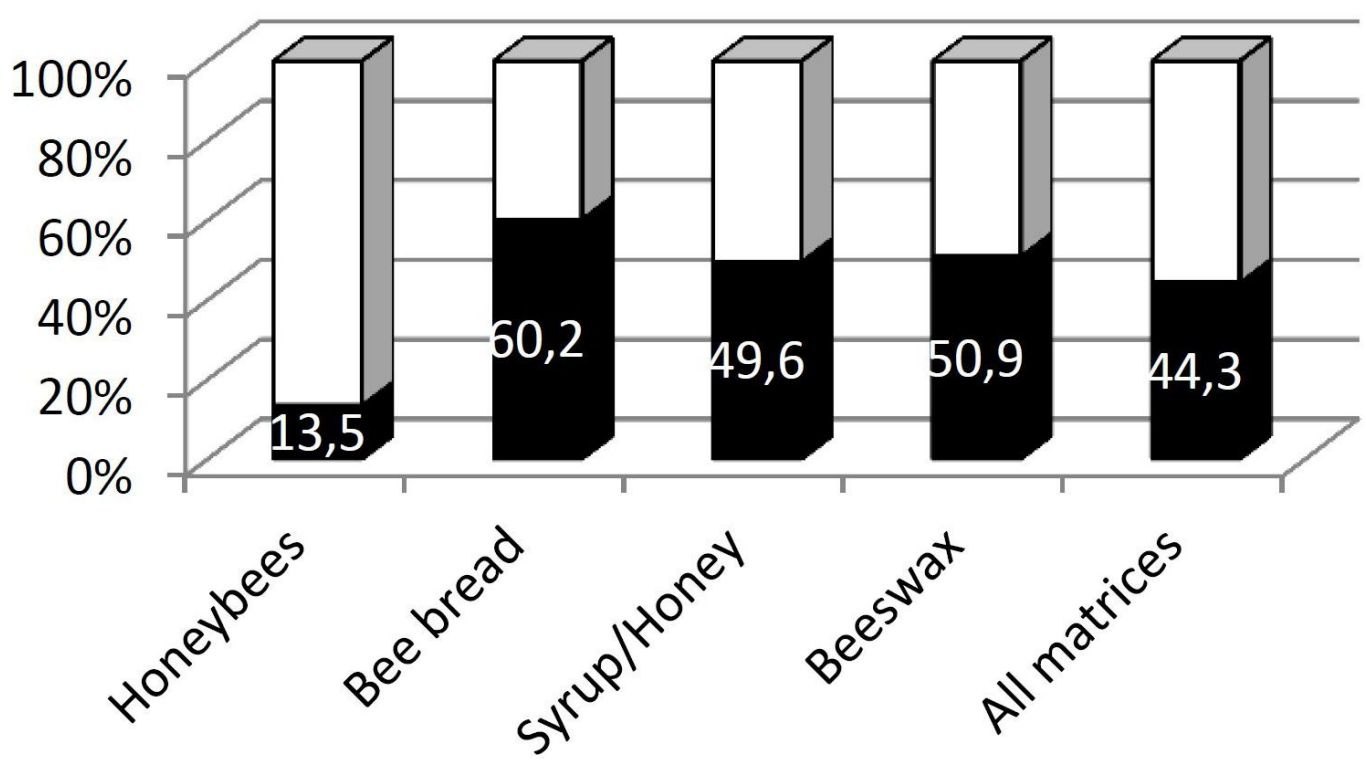

Fig. 1. Pesticide residues in bee-hive products and honey bees 
Table 4

Pesticide residues in winter food stores

\begin{tabular}{|c|c|c|c|c|c|c|c|}
\hline \multirow{3}{*}{ Compound } & \multicolumn{3}{|c|}{ Bee bread $(n=123)$} & \multicolumn{3}{|c|}{ Syrup/Honey ( $(\mathrm{=}$ 143) } & \multirow{3}{*}{$\begin{array}{l}\text { LOQ* } \\
\text { pollen/ } \\
\text { honey }\end{array}$} \\
\hline & \multirow{2}{*}{$\begin{array}{l}\text { Positive } \\
\text { samples } \\
\text { (\%) }\end{array}$} & \multicolumn{2}{|c|}{$\begin{array}{c}\text { Concentrations } \\
\text { (ng/g) }\end{array}$} & \multirow{2}{*}{$\begin{array}{c}\text { Positive } \\
\text { samples } \\
\text { (\%) }\end{array}$} & \multicolumn{2}{|c|}{$\begin{array}{c}\text { Concentrations } \\
(\mathrm{ng} / \mathrm{g})\end{array}$} & \\
\hline & & Mean & Max. & & Mean & Max. & \\
\hline Acetamiprid (I) & 15.4 & 10.3 & 32.8 & 31.5 & 1.6 & 19.5 & $1.0 / 0.5$ \\
\hline Azoxystrobin (F) & 7.3 & 6.9 & 12.3 & nd & nd & nd & $2.0 / 1.0$ \\
\hline Boscalid (F) & 18.7 & 124.9 & 1030.0 & nd & nd & nd & $12.0 / 5.0$ \\
\hline Captan (F) & 5.6 & 3426.7 & 9800.0 & nd & nd & nd & $2.0 / 1.0$ \\
\hline Carbendazim (F) & 30.1 & 7.1 & 44.6 & 12.6 & 1.8 & 3.1 & $1.0 / 0.5$ \\
\hline Dimethoate (I) & 9.7 & 36.4 & 162.7 & nd & nd & nd & $2.0 / 1.0$ \\
\hline Fenpropimorph (F) & 3.2 & 5.1 & 7.6 & nd & nd & nd & $1.0 / 0.5$ \\
\hline Fenpyroximate (I) & 0.8 & 3.2 & 3.2 & nd & nd & nd & $2.0 / 1.5$ \\
\hline Imidacloprid (I) & nd & nd & nd & 1.4 & 3.1 & 3.5 & $3.0 / 1.0$ \\
\hline Linuron $(\mathrm{H})$ & 0.8 & 68.6 & 68.6 & nd & nd & nd & $3.0 / 4.0$ \\
\hline Lenacil $(H)$ & 2.6 & $<\mathrm{LOQ}$ & $<\angle O Q$ & nd & nd & nd & $2.0 / 1.0$ \\
\hline Metamitron $(\mathrm{H})$ & 0.8 & 47.2 & 47.2 & nd & nd & nd & $3.0 / 2.0$ \\
\hline Metalaxyl (F) & 0.8 & 1.1 & 1.1 & nd & nd & nd & $1.0 / 0.5$ \\
\hline Methoxyfenozide (I) & 3.2 & 66.0 & 120.5 & nd & nd & nd & $0.5 / 0.5$ \\
\hline Рropamocarb (F) & 0.8 & 4.4 & 4.4 & nd & nd & nd & $3.0 / 2.0$ \\
\hline Prochloraz (F) & 0.8 & 2.9 & 2.9 & nd & nd & nd & $2.0 / 1.0$ \\
\hline Pendimethalin $(\mathrm{H})$ & 17.1 & 9.5 & 28.6 & nd & nd & nd & $4.0 / 2.0$ \\
\hline Pyridaben (I) & 0.8 & 3.2 & 3.2 & nd & nd & nd & $1.0 / 0.5$ \\
\hline Thiametoxam (I) & 0.8 & 4.3 & 4.3 & 0.7 & 13.3 & 13.3 & $1.5 / 0.5$ \\
\hline Thiacloprid (I) & 20.3 & 5.1 & 88.6 & 32.2 & 0.9 & 5.2 & $2.0 / 0.5$ \\
\hline Tebuconazole (F) & 9.7 & 99.7 & 387.0 & 1.4 & 1.2 & 1.3 & $6.0 / 1.0$ \\
\hline Thiophanate-methyl (F) & 9.7 & 34.7 & 110.6 & nd & nd & nd & $3.0 / 1.0$ \\
\hline
\end{tabular}

*LOQ - limit of quantification

$\mathrm{F}=$ fungicide, $\mathrm{I}=$ insecticide, $\mathrm{H}=$ =herbicide

nd = not detected

Pesticide residues in honeybees $(n=155)$

Table 5

\begin{tabular}{|c|c|c|c|c|}
\hline \multirow{2}{*}{ Compound } & \multirow{2}{*}{ Positive samples (\%) } & \multicolumn{2}{|c|}{ Concentration (ng/g) } & \multirow{2}{*}{$\mathrm{LOQ}^{*}$} \\
\hline & & Mean & Max. & \\
\hline Acetamiprid (I) & 5.8 & 1.1 & 1.3 & 1.0 \\
\hline Carbendazim (F) & 1.9 & 1.1 & 1.3 & 1.0 \\
\hline Dimethoate (I) & 3.2 & 1.3 & 1.5 & 1.0 \\
\hline Fenpropimorph (F) & 3.2 & 1.2 & 1.2 & 1.0 \\
\hline Fenpyroximate $(A)$ & 1.9 & 1.5 & 1.5 & 1.5 \\
\hline Imidacloprid (I) & 1.9 & 4.1 & 5.3 & 2.0 \\
\hline Propamocarb (F) & 1.9 & $<\mathrm{LOQ}$ & $<L O Q$ & 2.0 \\
\hline Pyridaben (I) & 1.9 & 1.4 & 1.8 & 1.0 \\
\hline Thiacloprid (I) & 1.9 & $<L O Q$ & $<\mathrm{LOQ}$ & 0.5 \\
\hline
\end{tabular}

* LOQ - limit of quantification

$\mathrm{F}=$ fungicide, $\mathrm{I}=$ insecticide, $\mathrm{H}=$ =herbicide 
two pesticides were found in $38.2 \%$ of samples. Insecticides and fungicides co-occurred in 37.3\% of positive samples. The most prevalent insecticides in pollen were thiacloprid (20.3\%), acetamiprid (15.4\%) and dimethoate (9.7\%). The most frequent fungicide residues were carbendazim (30.1\%) and boscalid (18.7\%). The greatest amount of residues was estimated for captan in a quantity of $3,426.7 \mathrm{ng} / \mathrm{g}$. The proportion of positive bee bread samples obtained from apiaries with high $(54.0 \%$ positive samples) and low colony losses (66.0\% positive samples) showed no significant differences in contamination (Chi-square test, $p=0.704$ ).

Among 143 of sugar food investigated samples, 71 samples in total revealed the residues of four insecticides and only two fungicides (Tab. 4). The most abundant compounds were systemic insecticides tiacloprid (32.2\%) and acetamiprid (31.5\%). The concentration of all pesticide residues in syrup/honey samples was very low (ppb). The share of contaminated honey samples from apiaries differing in scale of lost colonies overwinter was similar (Chi-square test, $p=0.103)$.

The results of the analysis of the 155 honey bee samples are presented in Tab. 5. The analysis of bees resulted in very rare detections. Small amounts of six insecticides and three fungicides were identified only in 21 samples. There were no significant differences in the proportion of bee positive samples between apiaries with high $(>10 \%)$ and low ( $\leq 10 \%)$ loss rates of overwintering honey bee colonies (Chi-square test, $p=0,363)$.

\section{DISCUSSION}

\section{Exposure to acaricide residues in beeswax}

An overview of world data proved that acaricides applied to hives during treatments against Varroa mites accumulate within the hives, mainly in wax. However, the level of acaricide residue contamination in Polish beeswax had been unknown. Our study shows substantial varroacides load for this bee product, residues of at

- Positive samples of beeswax from apiaries with high colony losses $(>10 \%)$

- Positive samples of beeswax from apiaries with low colony losses $(\leq 10 \%)$

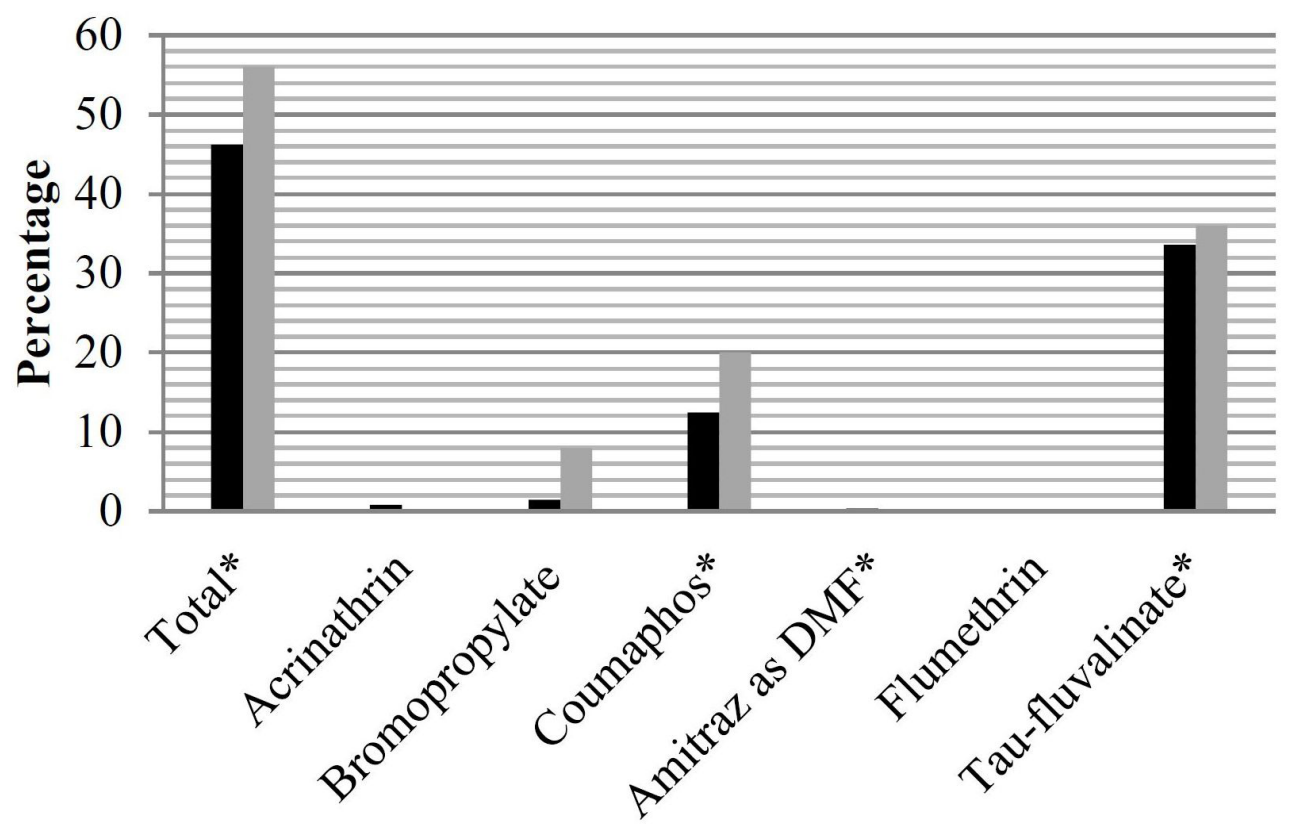

*(Chi-square test, $\mathrm{p} \leq 0.05$ )

Fig. 2. Acaricide residues in the brood nest wax samples collected from apiaries with high and low colony losses 
least one active ingredient have been detected in more than half of the analyzed samples. The main compounds that we found were tau-fluvalinate (39.9\%) and coumaphos, although the latter was noticed in a much lesser proportion of samples (14.7\%). According to the research of other authors, tau-fluvalinate and coumaphos belong to the most commonly found compounds (frequency of detection over 50\%) in beeswax (Schanzes-Bayo \& Goka, 2014). Tau-fluvalinate and coumaphos residues were present in 37\% and $61 \%$ of beeswax samples collected from German apiaries (a large number of samples contains $1-5 \mathrm{mg} / \mathrm{kg}$ of both active ingredients) and in $61.9 \%$ (mean concentration $0.196 \mathrm{mg} / \mathrm{kg}$ ) and $52.2 \%$ (on average $0.792 \mathrm{mg} / \mathrm{kg}$ ) of French beeswax samples, respectively (Wallner, 1999; Chauzat \& Faucon, 2007). In Italy, during the ten-year monitoring of beeswax present on the Italian market, $38 \%$ of samples were found to be contaminated with tau-fluvalinate (the average content in each year of the test ranged from 0.111 to $0.554 \mathrm{mg} / \mathrm{kg}$ ) and $49 \%$ with coumaphos (average annual content 0.063$0.831 \mathrm{mg} / \mathrm{kg}$ ) (Boi et al., 2016). Tau-fluvalinate (mean $1.310 \mathrm{mg} / \mathrm{kg}$ ) was detected in almost all the commercial beeswax samples analyzed in Spain, while coumaphos was confirmed in only $3.7 \%$ of samples, at an average concentration $0.067 \mathrm{mg} / \mathrm{kg}$ (Serra-Bonvehí \& OrantesBermejo, 2010). A definite broader beeswax contamination has been documented in USA, where both the frequency of fluvalinate and coumaphos detections, reached $98 \%$, at a mean concentration of 7.3 and $3.4 \mathrm{mg} / \mathrm{kg}$, respectively (Mullin et al., 2010). This means that most of the wax samples (83\%) simultaneously contained residues of those pesticides.

The fact that the level of Polish wax contamination was comparable to what European authors were presenting, was surprising and also worrisome. Pesticides used in apiculture and agricultureare the main pollution source of chemical compound residues in beeswax (Johnson, 2015). In contrast to the above-mentioned countries, veterinary medicinal products with coumaphos and fluvalinate has not been authorized in Poland for the treatment of V.destructor in the last several years. Moreover, the plant protection products containing coumaphos are not allowed for use in national agriculture, while tau-fluvalinate is approved only for oilseed rape protection under the Mavrik trade name. Nevertheless, the concentration of tau-fluvalinate and coumaphos residues in the beeswax turned out be the same or often even higher than those observed in France, Italy or Spain, where varroacides with tau-fluvalinate and/or coumaphos are approved. In such a context as this, the unauthorized varroacides would seem to be the main reason for Polish wax to be contaminated with coumaphos and presumably with tau-fluvalinate to large extent as well. This finding may be partly the result of the beeswax international trade.

Amitraz as an active ingredient of Apiwarol $^{\oplus}$ and Biowar 500 (formulations permitted for apiculture) has been utilized the most and the longest by Polish beekeepers for chemical treatment against Varroa mite invasion (Pohorecka et al., 2014). Despite widespread application, amitraz (as metabolite DMF) has been detected in a very small proportion of samples (3.3\%) and its mean concentration $(0.18 \mathrm{~g} / \mathrm{kg})$ tenfold lower than tau-fluvalinate. The similar results have also been obtained in other European countries, where amitraz is registered for treatment against $V$.destructor. In Spanish and Italian beeswax the amitraz metabolites on average amounted $0.029 \mathrm{mg} / \mathrm{kg}$ ( $14 \%$ of positive samples) and $0.033-0.273 \mathrm{mg} / \mathrm{kg}$ (6\% of positive samples), respectively (Serra-Bonvehí \& OrantesBermejo, 2010; Boi et al., 2016). In accordance with 004/141/EC Commission Decision, in European Union amitraz is forbidden as active substance of plant protection products, which significantly limits of honey bee exposure to this chemical compounds. In the USA, where the Environmental Protection Agency (US EPA) authorizes the use of amitraz in agriculture and as a veterinary miticide ( but not for its use in apiculture), amitraz metabolites (DMPF, DMA) were found in $60.0 \%$ (mean concentration $2.2 \mathrm{mg} / \mathrm{kg}$ ) and 34\% (mean concentration $0.7 \mathrm{mg} / \mathrm{kg}$ ) of beeswax samples (Mullin et al., 2010).

Amitraz decomposes very rapidly in beeswax (Korta et al., 2001), so its application creates 
Table 6

Relationship of the maximum residue detected in a sample of bee bread to the oral $L D_{50}$ for an adult worker honey bee, based on a consumption of $10 \mathrm{mg}$ of pollen per nurse bee per day and during the 10-day nursing phase

\begin{tabular}{|c|c|c|c|c|c|}
\hline Compound & $\begin{array}{c}\text { Maximum } \\
\text { residue } \\
\text { (ng/g) }\end{array}$ & $\begin{array}{l}\text { Maximum } \\
\text { amount of } \\
\text { pesticide } \\
\text { residues } \\
\text { ingested per } \\
\text { nurse bee } \\
\text { per day }(\mu g)\end{array}$ & $\begin{array}{l}\text { Percentage } \\
\text { of oral LD } \\
\text { per nurse } \\
\text { bee per day }\end{array}$ & $\begin{array}{c}\text { Percentage } \\
\text { of oral LD } \\
\text { per bee } \\
\text { during the } \\
\text { 10-day } \\
\text { nursing phase }\end{array}$ & $\begin{array}{c}\text { Acute toxicity } \\
\text { contact/oral }^{* *} \\
\text { (LD }_{50} \\
\mu g / b e e)\end{array}$ \\
\hline Acetamiprid (I) & 32.8 & 0.00039 & 0.003 & 0.03 & 7.9/14 \\
\hline Azoxystrobin (F) & 12.3 & 0.00015 & 0.0006 & 0.006 & $>200 />25$ \\
\hline Boscalid (F) & 1030.0 & 0.01236 & 0.007 & 0.07 & $>200 / 166$ \\
\hline Captan (F) & 9800.0 & 0.11760 & 0.1 & 1.0 & $25 / 91$ \\
\hline Carbendazim (F) & 44.6 & & & & $>50 /-$ \\
\hline Dimethoate (I) & 162.7 & 0.00195 & 1.1 & 11.0 & $0.12 / 0.17$ \\
\hline Fenpropimorph (F) & 7.6 & 0.00009 & 0.00009 & 0.0009 & $>100 />100$ \\
\hline Fenpyroximate (I) & 3.2 & & & & $11 /-$ \\
\hline Imidacloprid (I) & nd & & & & 0.059/0.0037 \\
\hline Linuron $(\mathrm{H})$ & 68.6 & & & & \\
\hline Lenacil $(\mathrm{H})$ & $<\mathrm{LOQ}^{*}$ & & & & \\
\hline Metamitron $(\mathrm{H})$ & 47.2 & & & & \\
\hline Metalaxyl (F) & 1.1 & 0.00001 & 0.000004 & 0.00004 & $141 / 269$ \\
\hline Methoxyfenozide (I) & 120.5 & 0.00144 & 0.001 & 0.01 & $>100 />100$ \\
\hline Propamocarb (F) & 4.4 & 0.00005 & 0.00005 & 0.0005 & $>100 / 99$ \\
\hline Prochloraz (F) & 2.9 & 0.00003 & 0.00005 & 0.0005 & $50 / 60$ \\
\hline Pendimethalin $(\mathrm{H})$ & 28.6 & & & & \\
\hline Pyridaben (I) & 3.2 & 0.00004 & 0.007 & 0.07 & $0.053 / 0.55$ \\
\hline Thiametoxam (I) & 4.3 & 0.00005 & 1.0 & 10.0 & 0.025/0.005 \\
\hline Thiacloprid (I) & 88.6 & 0.00106 & 0.006 & 0.06 & $36 / 17$ \\
\hline Tebuconazole (F) & 387.0 & 0.00464 & 0.005 & 0.05 & $>200 / 83$ \\
\hline $\begin{array}{l}\text { Thiophanate-methyl } \\
\text { (F) }\end{array}$ & 110.6 & 0.00132 & 0.001 & 0.01 & $>100 />100$ \\
\hline
\end{tabular}

* LOQ - limit of quantification

**Sources: Agritox database or US EPA database

$\mathrm{F}=$ fungicide, I=insecticide, $\mathrm{H}=$ herbicide

nd = not detected

a lower risk of wax contamination compared to the more stable lipophilic pyrethroid and organophosphorus compounds, although, on the other hand, the toxicity of amitraz breakdown products to honey bees has never been directly estimated (Johnson, 2015). Recent study showed that the most frequent pesticide residues identified in live honey bees were amitraz me- tabolites (Kiljanek et al. 2017), so it could mean the honey bees may tolerate amitraz as an acaricide (Johnson et al.,2013). However, amitraz pre-treatment may increase the toxicity of tau-fluvalinate 5 -fold, as a results of interactions between formamidines and pyrethroids. (Johnson et al., 2013).

Tau-fluvalinate is highly persistent in wax, so its 
residues pose the highest risk by the long-term contact exposure of winter bees to contaminated combs. While most pyrethroids are highly toxic to honey bees, tau-fluvalinate is now considered as relatively less harmful and better tolerated in large part due to a rapid detoxification by cytochrome P450 monooxygenases (Johnson et al., 2006). Standard risk assessment complemented with new approaches that take into account time-cumulative effects over time conducted by (Sanchez-Bayo \& Goka, 2014) confirms that the remaining tau-fluvalinate (and coumaphos also) at an average concentration level found so far $(0.1 \mathrm{mg} / \mathrm{kg})$ pose a very low risk through contact with pollen and with wax (as the authors suppose). Unfortunately, the average concentration of tau-fluvalinate and coumaphos in beeswax, 1.6 and $0.99 \mathrm{mg} / \mathrm{kg}$, respectively, which has been documented in our monitoring, exceeds the average content of these substances in pollen at least tenfold.

In order to estimate the risk of bees being affected by contaminated beeswax we used a Hazard Quotients (HQ) expressed as a ratio of pesticide residues (in $\mu \mathrm{g} / \mathrm{kg}$ ) to their lethal dose (in $\mu /$ bee) (Stoner \& Eitzer, 2013). Our calculations are based on the contact $L_{50}$ values $12 \mu \mathrm{g} /$ bee for tau-fluvalinate (PPDB) and 20 $\mu \mathrm{g} /$ bee for coumaphos (PPDB), and the maximum concentration of these compounds in beeswax found in present study (the worst case scenario). Tau-fluwalinate and coumaphos had the HQ 675 and 551, respectively. In view of the European and Mediterranean Plant Protection Organization standards (EPPO, 2010) and European Food Safety Authority guidelines (EFSA, 2013) some researchers recognized pesticide load as "relevant" if had a HQ scores greater than 50 and "elevated" if the total $\mathrm{HQ}$ in a sample was 1,000 or more (Stoner et al., 2013; Kiljanek et al., 2017). Pesticide residues are substantially higher in beeswax, and transmission routes are less known in comparison with pollen or nectar. For this reason, Traynor et al. (2016) classified as "elevated" only samples of beeswax with a total $\mathrm{HQ}$ (the sum of all pesticide residues concentrations in $\mathrm{ppb}$ divided by their respective $L_{50}$ in $\mu$ g/bee for each residue in a given sample) greater than 5,000. These authors found clear links between an increase in the total number of pesticides in wax and colony mortality. According to our results, the beeswax with tau-fluvalinate and coumaphos coming from hives with both high and low winter survival rates had similar contamination levels (frequency, concentration), which indicates a comparable extent of exposure to these pesticides. However, in the present study only acaricide residues were taken into consideration and it is highly likely that far more other pesticides (insecticides, fungicides) were present in beeswax.

Exposure to plant protection pesticide residues in winter food stores

In line with our expectations, the toxicological analysis of the winter carbohydrate (syrup/ honey) and protein food stocks (bee bread) has shown a decidedly greater contamination of pollen. Although, the share of contaminated bee bread and sugar food samples was similar (60.2\% and $49.6 \%$, respectively), the number of active substances and their concentrations detected in sugar food were very limited and low. We noticed the presence of twenty-two pesticides in bee bread and only six in syrup/honey. These differences could be explained by the fact that most of food samples were obtained from overwintering honey bee colonies, so the majority of the carbohydrate food stocks had been formed from syrup. This conclusion is confirmed by our earlier findings, which showed a much higher contamination of real nectar/honey samples (Szczęsna et al., 2009; Pohorecka et al., 2012). Twenty nine compounds (among 30 surveyed) in $29 \%$ of honey samples collected in the summer from Polish apiaries were also found by Bargańska et al. (2013). The most frequently detected active substances were identified in the following order: profenofos (I), dimoxystrobin $(F)$, diazinon (I). Eight of the thirteen pesticides were detected in Polish honey analyzed by Kujawski \& Namieśnik (2011) and 87\% of the samples were contaminated. In this study, the most common pesticide residue was clothianidin (I), which had been found in $65 \%$ of samples.

Widespread honey contamination was also observed in Italy, where the majority of the 
samples (94\%) contained at least one of the pesticides tested (Panseri et al., 2014). Likewise, Chiesa et al. (2016) noted high residue frequency in organic honey produced in different geographic areas of Italy. Interestingly, pesticides have rarely been identified in French honey. No residues were detected in $57 \%$ of samples analyzed, the remaining contained a total 10 (from 39 investigated) of different analytes. The most frequent residues in honey were imidacloprid (21\%) and its metabolite 6-chloronicotinic acid (18\%) (Chauzat et al., 2011). Investigations of Austrian honey have shown acetamiprid, thiacloprid and thiamethoxam residues in samples (Tanner \& Czerwenka, 2011). Residues in honey include mainly systemic compounds, among which the most commonly found are neonicotinoid insecticides, hydrophilic fungicides and herbicides (Schanzes-Bayo \& Goka, 2014).

A total of 77 pesticides have been found in honey or nectar so far, whilst in pollen 124. The majority of PPP are fat soluble, so pollen is more susceptible to contamination. According to Schanzes-Bayo \& Goka (2014) among the three factors relevant in risk assessment, which included quantity of residues, prevalence and toxicity, the latter which is the most important. Among the pesticides that we have found in pollen, fourteen belonged to fungicides and herbicides, which are generally less toxic to bees compared to insecticides, and only five (carbendazim, boskalid, pendimethalin, tebuconazole, and thiophanate-methyl) occurred more frequently (in the range of $10-30 \%$ of samples). Only three (thiametoxam, dimethoate and pyridaben) from ten insecticides present in pollen were classified as highly toxic but. The less toxic neonicotinoid insecticides - acetamiprid and thiacloprid - stood out due to their higher prevalence.

Exposure of winter bees to pesticide residues in pollen mainly occurs through the ingestion of contaminated pollen. We calculated the maximum daily doses of residues consumed with the maximum daily rate of bee bread (12 mg, Rortais et al., 2005) into a context of the hazard to a nurse bees (Tab. 6). Dimethoate and thiametoxam residues posed higher risks, daily and ten-day intake equal to the consumption of $1 \%$ and $10 \%$ of their oral $L_{50^{\prime}}$ respectively. According to EFSA guidance the environmental exposure of honey bees to pesticide residues higher than 1/10thof lethal dose would create a risk of initial bee acute toxicity. However, in our study, these two compounds appeared only once (thiametoxam) or in a few samples (dimethoate). Based on dietary risk evaluated for 77 compounds by Schanzes-Bayo \& Goka (2014), we concluded that among the low residue loads of pesticide that we had found, the even more prevalent insecticides, thiacloprid and acetamiprid also posed a minor threat. Nevertheless, in more than half of the apiaries, the long-lived winter bees (consuming of $2 \mathrm{mg}$ bee bread per day, Crailsheim et al., 1993) likely to have been exposed to sublethal pesticide doses up to 100 days. Continuous contact and dietary exposure to a low residues affect the behavior of individual bees and reproduction of honey bee colonies (El Hassani et al., 2008; Berry et al., 2013)

A risk assessments of oral and contact toxicity of the individual pesticides is insufficient in case of simultaneous exposure to different classes of pesticides, which may have a synergistic toxicity to bees. Iwasa et al. (2004) provided convincing evidence of how the addition of piperonyl butoxide and the fungicides triflumizole and propiconazole increased the acute toxicity (24-h $L_{50^{\prime}}$ topical application) of acetamiprid and thiacloprid. Of the 123 analyzed pollen samples $22.0 \%$ were polluted with one compound and $38.2 \%$ were contaminated with more than one pesticide. Co-occurring pesticides did not constitute mixtures that had already shown synergistic toxicity (SchanzesBayo \& Goka, 2014; Zhu et al., 2014), although only a very small fraction was studied for synergistic effects. In addition, the prevalence of pesticides in pollen from apiaries with high and low colony losses has been comparable. These effects suggest that the found levels of the pesticide contamination do not have a significant influence on the destruction of overwintering honey bee colonies. 
Agrochemical contamination of bee bread not been evaluated in Poland before, so our results can be compared only to the data from other countries, although we are aware that there are large methodological and analytical differences among studies published so far e.g. different range of identified compounds, limit of detection (LOD), limit of quantification (LOQ) (Tette et al., 2016). Nonetheless, the diverse tests results may also be the result of various models of agrochemical treatments in particular regions of the world.

In some aspects our findings are similar to the results obtained in France and Germany where the positive samples of pollen reached 69\% and $76 \%$ (pollen collected after the blooming period of oilseed rape) and were polluted with 22 and 42 active substances (32\% with one pesticide) of the 41 and 258 searched, respectively (Chauzat et al., 2011, Genersch et al., 2010). In the French studies imidacloprid (33\%) and 6-chloronicotinic acid (40\%) were the most prevalent chemicals, while in the German ones boscalid (47\%), coumaphos (37\%), thiacloprid (33\%) and terbuthylazine (35\%). In other parts of Europe less common pollen contamination has been shown. Pesticide residues were detected in $27 \%$ of Italian bee bread samples and $42 \%$ of Spanish pollen samples collected in spring, and in $31 \%$ of samples collected in autumn. The most frequently detected were fluvalinate and chlorfenvinphos (Bernal et al., 2010, Porrini et al., 2016). In the Netherlands, van der Zee et al. (2015) considered agricultural pesticides, neonicotinoids in particular, as one of many possible risk factors related to winter loss. From all the detected pesticides, only one group of neonicotinoids (thiacloprid, acetamiprid, and imidacloprid) was present in a sufficient number of samples. American researchers have noticed a definitely higher levels of pesticides in pollen, in which residues of 98 compounds (from 200 analyzed) were present in $99 \%$ of samples, with up to 31 different pesticides found in a single sample. $A$ single sample contained on average 7.1 different pesticides; the most frequently found were residues of fluvalinate (88\%) and coumaphos (75\%), followed in order by chlorothalonil (53\%), pendimethalin (45\%), chlorpyrifos (44\%) and amitraz (31\%). The insecticides chlorothalonil aldicarb, carbaryl, chlorpyrifos and imidacloprid, fungicides boscalid, captan and myclobutanil, and herbicide pendimethalin were been assayed at ppm levels (Mullin et al., 2010). A direct relationships between pesticide residues found in stored pollen and colony losses was disclosed in none of the cited monitoring.

\section{Plant protection pesticide residues in dead honey bees}

We found nine pesticides in a total of $13.5 \%$ of honey bee samples, while in most of the samples only one compound was present. The quantity of all the pesticides we had detected in bees was much below the $L D_{50}$ values specified for adult honey bees (Tab. 6). Nevertheless, some of the identified substances characterized high toxicity to bees. These include dimethoate $\left(\mathrm{LD}_{50}\right.$ contact - $120 \mathrm{ng} / \mathrm{bee}$, оral - $170 \mathrm{ng} / \mathrm{bee}$, Sanchez-Bayo \& Goka, 2014), pyridaben (contact $\mathrm{LD}_{50}$ - $53 \mathrm{ng} / \mathrm{bee}$, оral - $55 \mathrm{ng} / \mathrm{bee}$, Sanchez-Bayo \& Goka, 2014) and imidacloprid (contact $L_{50}$ between 18-104 ng/bee, oral $L_{50}$ 4-81 ng/bee, Blacquière et al., 2012) However, these chemicals cannot be considered the cause of mass loss of colonies, because only a few samples were contaminated with them.

Obviously, some colonies were exposed to higher doses of pesticides as clearly indicated by results of the contamination level of wax and pollen stored in the nests of the surveyed bee colonies (Tab. 3 and 4). Pesticides can be biotransformed and/or excreted, which makes them impossible to detect. Furthermore, we analyzed the bees that had died in the winter and the time that had passed, since that could have also caused the breakdown of pesticides. Nonetheless, in samples of poisoned honey bees, there are observed a significantly higher frequency and quantity of pesticide residues in compared to samples of live honey bees (Kiljanek et.al., 2017). Simultaneous analysis of 200 pesticides and metabolites conducted by these authors (2016) revealed 57 pesticides in poisoned honey bees. In a total of 74 samples of poisoned honey bees, only one sample was free of pesticides. The most abundant active 
substances were highly toxic organophosphates: chlorpyrifos (38 samples), dimethoate (30 samples) and neonicotinoid clothianidin (22 samples). The concentration of several pesticides exceeded the $L D_{50}$ in some samples. Severe contamination of honey bees from suspected pesticide poisoned colonies has been noted by Łozowicka (2013) and Bargańska et al. (2014). All samples were positive, and a large number of them contained more than one pesticide and with high residue concentration. The pesticides most often found in honey bees were highly toxic organophosphorus insecticides (chlorpyrifos heptenophos, methidathion) and pyrethroids (bifenthrin, cypermethrin). Similarly, analyses of samples received after the honey bee death incidents that occurred in Greece confirmed the presence of pesticide residues in $73 \%$ of them. In the majority of cases the bees were polluted with highly toxic pesticides: clothianidin, chlorpyrifos ethyl, thiamethoxam and imidacloprid (Kasiotis et al., 2014).

The researchers that used honey bees as bioindicators of environmental contamination with plant protection products found that even more extensively contaminated hive products (compared to a level detected in our experiments) did not necessarily cause the death of bee colonies. When the bee colonies were exposed to 22 pesticides present in pollen (70\% positive samples), to 10 compounds in honey (43\% samples), and to 15 pesticides in beeswax (65\% samples), only the residues of 25 analytes were found in $44 \%$ samples of live honey bees (Chauzat et al., 2011). However, the majority of bee samples contained only one compound and the concentration of the most abundant substances (imidacloprid and 6-chloronicotinic acid) was very low. Along with the increased exposure $(99 \%$ of pollen samples with 98 pesticides and $99 \%$ of beeswax samples contaminated with 87 compounds) the prevalence of pesticides in honey bees drastically increased - a total of 46 substances in $91 \%$ of contaminated bee samples (Mullin et al., 2010).

The broad analysis of the pesticide residues in the hive environment conducted with the aim of searching for the causes of the high mortality of overwintered honey bee colonies has provided the first data on this issue in Poland. Acquired knowledge about exposure to pesticides (their prevalence and residue loads) of winter bees allowed the threat posed by these compounds to be assessed. We took into account various sources and routes for the exposure such as ingestion of contaminated food and contact with polluted beeswax as well as the acute, chronic and mixture of toxicities. We found that samples of beeswax were mainly contaminated with taufluvalinate, whose contact toxicity is recognized as low. Although, the bee bread contained the greatest number of pesticide residues, we assessed that the level of contamination created a relatively low toxicological hazard for colonies. Sugar food, which had been formed primarily from syrup, additionally reduced the potential source of pesticide residues. Similar exposure to pesticide residues in apiaries with high and low rates of winter colony mortality was an additional argument leading to the conclusion that in the surveyed apiaries contamination of the hive environment with pesticides was not the main reason for the decline of colonies during the winter. While, in apiaries with high colony losses the assessment of the epizootic state of these colonies showed significantly higher V. destructor infestation, the prevalence of deformed wing virus and acute bee paralysis virus (Pohorecka et al., 2011; Pohorecka et al., 2014). Finally, the present results confirm the previously proven thesis that in most national apiaries the mentioned above pathogens аге a primary and direct cause of the increased winter mortality in honey bee colonies, but this does not mean that chronic exposure to pesticide does not have a side effect on bees. It would be expected that the co-occurrence of pesticide residues and pathogens/parasites may diminish the threshold of infestation/infection at which the colony collapses.

\section{ACKNOWLEDGMENTS}

We appreciate the thoughtful comments of reviewers who helped to improve the manuscript. We thank the colleagues from 
Department of Honeybee Diseases, National Veterinary Research Institute, and Bee Products Testing Laboratory, and Food Safety Laboratory, Research Institute of Horticulture in Skierniewice for their laboratory assistance.

This study was supported by the Ministry of Science and Higher Education, COST ACTION FA0803, grant number 527/N-COST/2009/0.

\section{REFERENCES}

Adamczyk, S., Lázaro, R., Pérez-Arquillué, C., \& Herrera, A. (2007). Determination of synthetic acaricides residues in beeswax by high-performance liqvid chromatography with photodiode array detector. Analitica Chimca Acta, 581, 95-101. https://dx.doi. org/10.1016/j.aca.2006.07.085

Agritox Agence nationale de sécurité sanitaire de I'alimentation, de l'environnement et du travail in France. Available: , http://www.dive.afssa.fr/agritox/ index.php. Accessed 2016 November 12.

Anastassiades, M., Lehotay, S.I., Stajnbaher, D., \& Schenck, F.). (2003). Fast and easy multiresidue method employing acetonitrile extraction/partitioning and "dispersive solid-phase extraction" for the determination of pesticide residues in produce. Journal of AOAC International, 86, 412-31.

Bargańska, Ż., Ślebioda, M., \& Namieśnik J. (2014). Determination of pesticide residues in honey bees using modified QUEChERS sample work-up and liquid chromatography-tandem mass spectrometry. Molecules, 19, 2911-2924. doi:10.3390/molecules19032911

Bargańska, Z., Ślebioda, M., \& Namieśnik J. (2013). Pesticide residues levels in honey from apiaries located of Northern Poland. Food Control, 37, 196-201. https://dx.doi.org/10.1016/j.foodcont.2012.09.049

Belzunces, L.P., Tchamitchian, S., \& Brunet, J-L. (2012). Neural effects of insecticides in the honey bee. Apidologie, 43(3), 348-370. doi:10.1007/s13592012-0134-0

Bernal, J., Garrido-Bailon, E., Nozal, M.jd, Gonzalez-
Porto, A.V., Martin-Hernandez, R., Diego, J.C., ... Higes, M. (2010). Overview of pesticide residues in stored pollen and their potential effect on bee colony (Apis mellifera) losses in Spain. Journal of Economic Entomology, 103, 1964-1971. doi:10.1603/ec10235

Berry, J.A., Hood, W.M., Pietravalle, S., \& Delaplane, K.S. (2013). Field-level sublethal effects of approved bee hive chemicals on honey bees (Apis mellifera L). PLOS ONE, 8(10):e76536. https://dx.doi.org/10.1371/ journal.pone.0076536

Blacquière, T., Smagghe, G., van Gestel, C.A.M. \& Mommaerts, V. (2012). Neonicotinoids in bees: a review on concentrations, side-effects and risk assessment. Ecotoxicology, 27, 973. doi:10.1007/s10646012-0863-x

Bogdanov, S., Kilchenmann, V. \& Butikofer, U. (2003). Determination of acaricide residues in beeswax collaborative study. Apiacta, 3, 235-245.

Boi, M., Serra, G., Colombo, R., Lodesani, M., Massi, S., Costa, C. (2016). A 10 year survey of acaricide residues in beeswax analysed in Italy. Pest Management Science, 72, 1366-1372. doi:10.1002/ps.4161

Crailsheim, K., Hrassnigg, N., Gmeinbauer, R., Szolderits, M.J., Schneider, L.H.W., Brosch U. (1993). Pollen utilization in non-breeding honeybees in winter. Journal Insect Physiology, 39, 369-373. doi:10.1016/00221910(93)90024-L

Chauzat, M.P., \& Faucon, J.P. (2007). Pesticide residues in beeswax samples collected from honey bee colonies (Apis mellifera L.) in France. Pest Management Science, 63, 1100-1106. doi:10.1002/ps.145

Chauzat, M-P., Martel, A. C., Cougoule, N., Porta, P., Lachaize, J., Zeggane, S., .... Faucon, J.P. (2011). An assessment of honeybee colony matrices, Apis mellifera (Hymenoptera: Apidae) to monitor pesticide presence in continental France. Environmental Toxicology and Chemistry, 30, 103-111. doi:10.1002/ etc.361

Chiesa, L. M., Labella, G. F., Giorgi, A., Panseri, S., Pavlovic, R., Bonacci, S., Arioli, F. (2016). The occurrence 
of pesticides and persistent organic pollutants in Italian organic honeys from different productive areas in relation to potential environmental contamination. Chemosphere, 154, 482-490. https://dx.doi. org/10.1016/j.chemosphere.2016.04.00

Commission Decision 2004/141/EC of 12 February 2004 concerning the non-inclusion of amitraz in Annex I to Council Directive 91/414/EEC and the withdrawal of authorizations for plant protection products containing this active substance (Text with EEA relevance) (notified under document number C(2004) 332)

Desneux, N., Decourtye, A., \& Delpuech, J.M. (2007). The sublethal effects of pesticides on beneficial Arthropods. Annual Review of Entomology, 52, 81106. doi:10.1146/annurev.ento.52.110405.091440

EFSA (European Food Safety Authority). (2013). Guidance on the risk assessment of plant protection products on bees (Apis mellifera, Bombus spp. and solitary bees). EFSA Journal, 17,3295.

El Hassani, A. K., Dacher, M., Garry, V., Lambin, M., Gauthie, M., Armengaud, C. (2008). Effects of sublethal doses of acetamiprid and thiamethoxam on the behavior of the honeybee (Apis mellifera). Archives of Environmental Contamination and Toxicology, 54, 653-661. doi:10.1007/s00244-007-9071-8

EPPO (European and Mediterranean Plant Protection Organization). (2010). Environmental risk assessment scheme for plant protection products. EPPO Bulletin 40(3), 323-331.

Fries, l., Wallner, K., \& Rosenkranz, P. (1998). Effects on Varroa jacobsoni from acaricides in beeswax. Journal of Apicultural Research, 37, 85-90. http:// dx.doi.org/10.1080/00218839.1998.11100959

Genersch, E., von der Ohe, W., Kaatz, H., Schroeder, A., Otten,C., Büchler, R., ... Rosenkranz, P. (2010). The German bee monitoring project: a long term study to understand periodically high winter losses of honey bee colonies. Apidologie, 41, 332-352. http://dx.doi. org/10.1051/apido/2010014
Goulson, D. (2013). An overview of the environmental risks posed by neonicotinoid insecticides. Journal of Applied Ecology, 50, 977-987, doi:10.1111/13652664.12111

Iwasa, T., Motoyama, N., Ambrose, J.T., \& Roe, M.R. (2004). Mechanism for the differential toxicity of neonicotinoid insecticides in the honey bee, Apis mellifera. Crop Protection, 23, 371-378. http://doi. org/10.1016/j.cropro.2003.08.018

Jimenez, J.J., Bernal, J.L., Del Nozal, M.J., \& Martin, M.T. (2005). Residues of organic contaminants in beeswax. European Journal of Lipid and Technology, 107, 896-902. doi: 10.1002/ejlt.200500284

Johnson, R.M. (2015). Honey bee toxicology. Annual Review of Entomology, 60, 418-434. doi:10.1146/ annurev-ento-011613-162005

Johnson, R.M., Dahlgren, L., Siegfried, B.D., \& Ellis, M.D. (2013). Acaricide, fungicide and drug interactions in honey bees (Apis mellifera). PLOS ONE 8, e54092. http://dx.doi.org/10.1371/journal.pone.0054092.

Johnson, R.M., Ellis, M.D., Mullin C.A., \& Frazier M. (2010). Pesticides and honey bee toxicitiy - USA. Apidologie, 41, 312-331. http://dx.doi.org/10.1051/ apido/2010018

Johnson, R.M., Wen, Z., Schuler, M.A., \& Berenbaum, M.R. (2006). Mediation of pyrethroid insecticide toxicity to honey bees (Hymenoptera: Apidae) by cytochrome P450 monooxygenases. Journal of Economic Entomology, 99, 1046-1050. https://dx.doi. org/10.1603/0022-0493-99.4.1046

Kasiotis, K. M., Anagnostopoulos, C., Anastasiadou, P., \& Machera, K. (2014). Pesticide residues in honey bees, honey and bee pollen by LC-MS/MS screening: reported death incidents in honey bees. Science of The Total Environment, 485, 633-642. https:// dx.doi.org/10.1016/j.scitotenv.2014.03.042

Kiljanek, T., Niewiadowska, A., Gaweł M., Semeniuk, S., Borzęcka, M., Posyniak, A., Pohorecka, K. (2017). Multiple pesticide residues in live and poisoned honeybees - Preliminary exposure assessment. Chem- 
osphere, 175, 36-44.

Kiljanek, T., Niewiadowska, A., Semeniuk, S., Gaweł, M., Borzęcka, M., Posyniak, A. (2016). Multi-residue method for the determination of pesticides and pesticide metabolites in honey bees by liquid and gas chromatography coupled with tandem mass spectrometry -Honeybee poisoning incidents. Journal of Chromatography A, 1435, 100-114. http://dx. doi.org/10.1016/j.chroma.2016.01.045

Korta, E., Bakkali, A., Berrueta, L.A., Gallo, B., Vincent, P., Bogdanov, S. (2003). Determination of amitraz and other acaricide residues in beeswax. Analitica Chimca Acta, 475, 97-103. http://dx.doi.org/10.1016/ s0003-2670(02)01221-7

Korta, E., Bakkali, A., Berrueta, L.A., Gallo, B., Vincent, F., Kilchenmann, V., Bogdanov, S. (2001). Study of acaricide stability in honey. Characterization of amitraz degradation products in honey and beeswax. Journal of Agricultural and Food Chemistry, 49, 5835-5842. doi:10.1021/jf010787s

Kujawski, M.W., \& Namieśnik J. (2011). Levels of 13 multi-class pesticide residues in Polish honeys determined by LC-ESI-MS/M. Food Control, 22, 914-919. http://dx.doi.org/10.1016/j.foodcont.2010.11.024

Lodesani, M., Costa, C., Serra, G., Colombo, R., Sabatini, A.G. (2008). Acaricide residues in beeswax after conversion to organic beekeeping methods. Apidologie, 39, 324-333. doi:10.1051/apido:2008012

Lundin, O., Rundlöf, M., Smith, H.G., Fries, I., Bommarco, R. (2015). Neonicotinoid insecticides and their impacts on bees: A systematic review of research approaches and identification of knowledge gaps. PLOS ONE, 10(8): e0136928. doi:10.1371/journal.pone.0136928

Łozowicka, B. (2013).The development, validation and application of a CC-dual detector (NPD-ECD) multi-pesticide residue method for monitoring bee poisoning incidents. Ecotoxicology and Environmental Safety, Nov, 97, 210-22. doi:10.1016/j. ecoenv.2013.07.010.
Mullin, C. A., Frazier, M., Frazier, J. L., Ashcraft, S., Simonds, R., Pettis, J. S. (2010). High levels of miticides and agrochemicals in North American apiaries: implications for honey bee health. PLOS ONE, 5(3), e9754. doi:10.1371/journal.pone.0009754

Panseri, S., Catalano, A., Giorgi, A., Arioli, F., Procopio, A., Britti, D., Chiesa, L. (2014). Occurrence of pesticide residues in Italian honey from different areas in relation to its potential contamination sources. Food Control, 38, 150-156. http://dx.doi.org/10.1016/j. foodcont.2013.10.024

Pilling, E.D., \& Jepson, P.C. (1993). Synergism between EBI fungicides and a pyrethroid insecticide in the honeybee (Apis mellifera). Pesticide Science, 39, 293-297. doi:10.1002/ps.2780390407

Pohorecka, K., Bober, A., Skubida, M., Zdańska, D., Torój, K. (2014). A comparative study of environmental conditions, bee management and the epidemiological situation in apiaries varying in the level of colony losses. Journal of Apicultural Science, 58(2), 107-132. doi:10.2478/jas-2014-0027

Pohorecka, K., Skubida, P., Miszczak, A., Semkiw, P." Sikorski, P., Zagibajło, K.,.... Bober, A. (2012). Residues of neonicotinoid insecticides in bee collected plant materials from oilseed rape crops and their effect on bee colonies. Journal of Apicultural Science, 56(2), 115-134. doi:10.2478/v10289-012-0029-3

Pohorecka, K., Zdańska, D., Bober, A., Skubida, M. (2011). First detection of Israeli acute paralysis virus (IAPV) in Poland and phylogenetic analysis of the isolates. Journal of Apicultural Science, 55(2), 149159.

Porrini, C., Mutinelli, F., Bortolotti, L., Granato, A., Laurenson, L., Roberts, K., ....Lodesani, M. (2016). The Status of honey bee health in Italy: Results from the Nationwide Bee Monitoring Network. PLOS ONE, 11(5):e0155411 doi: 10.1371/journal.pone.0155411

PPDB.Pesticide Properties Database, http://sitem. herts.ac.uk/aeru/ppdb/en/index.htm (accessed $12.12 .16)$ 
Rortais, A., Arnold, G., Halm, M.P. \& Touffet-Briens, F. (2005). Modes of honeybees exposure to systemic insecticides: Estimated amounts of contaminated pollen and nectar consumed by different categories of bees. Apidologie, 36, 71-83. doi:10.1051/apido:2004071.

Sanchez-Bayo, F., \& Goka, K. (2014). Pesticide residues and bees - a risk assessment PLOS ONE, 9(4): e94482. http://dx.doi.org/10.1371/journal. pone.0094482

Serra-Bonvehí, J., \& Orantes-Bermejo, J. (2010). Acaricides and their residues in Spanish commercial beeswax. Pest Management Science, 66(11), 1230-1235. doi:10.1002/ps.1999.

Smirle M.J, \& Winston M.L. 1987. Intercolony variation in pesticide detoxification by the honey bee (Hymenoptera: Apidae). Journal of Economic Entomology, 891), 5-8. http://dx.doi.org/10.1093/jee/80.1.5

Statistica v.10 (2011) StatSoft Inc.

Stoner, K.A. \& Eitzer, B.D. (2013) Using a Hazard Quotient to evaluate pesticide residues detected in pollen trapped from honey bees (Apis mellifera) in Connecticut . PLOS ONE 8(10): e77550. https://doi. org/10.1371/journal.pone.0077550

Szczęsna, T., Rybak-Chmielewska, H., Waś, E., Pohoreck,a K. (2009). Study on sulphonamide residues in honey. Journal of Apiculture Science, 53 (2), 39-47.

Tanner, G., \& Czerwenka, C. (2011). LC-MS/MS analysis of neonicotinoid insecticides in honey: methodology and residue findings in Austrian honeys. Journal of Agricultural and Food Chemistry, 59(23), 12271-12277. doi:10.1021/jf202775m

Tette, P.A., Rocha Guidi, L., Glória, M.B., \& Fernandes, C. (2016). Pesticides in honey: A review on chromatographic analytical methods. Talanta, 149. 124-141. http://dx.doi.org/10.1016/j.talanta.2015.11.045

Traynor, K. S., Pettis, J.S., Tarpy, R.D.,Mullin Ch.A., Frazier, J.L., Frazier, M., vanEngelsdorp, D. (2016). In-hive pesticide exposome: assessing risks to migratory honey bees from in-hive pesticide contamination in the Eastern United States. Science Report, 6, 33207. doi: 10.1038/srep33207 (2016).

US EPA Pesticide Ecotoxicity Database of the Office of Pesticide Programs, Ecological Fate and Effects Division. Available: http://www.ipmcenters.org/Ecotox/. Accessed 2016 November 10.

Wahl, O., \& Ulm, K. (1983). Influence of pollen feeding and physiological condition on pesticide sensitivity of the honey bee Apis mellifera carnica. Oecologia, 59(1):106-28

Wallner, K. (1999). Varroacides and their residues in bee products. Apidologie, 30,235-248. http://dx.doi. org/10.1051/apido:19990212

Wiest, L., Bulete, A., Giroud, B., Fratta, C., Amic, S., Lambert, O., Pouliquen. H., Arnaudguilhem, C. (2011). Multiresidue analysis of 80 environmental contaminants in honeys, honey bees and pollens by one extraction procedure followed by liquid and gas chromatography coupled with mass spectrometric detection. Journal of Chromatography A, 1218, 5743-56. http:// dx.doi.org/10.1016/j.chroma.2011.06.079

van der Zee, R., Pisa, L., Andonov, S., Brodschneider, R., Charriere, J-D., Chlebo, R., ... Wilkins, S. (2012) Managed honey bee colony losses in Canada, China, Europe, Israel and Turkey, for the winters of 20082009 and 2009-2010. Journal of Apicultural Research 57(1), 100-114. doi:10.3896/IBRA.1.51.1.12

van der Zee, R., Gray, A., Pisa, L. \& de Rijk, T. (2015) An observational study of honey bee colony winter losses and their association with Varroa destructor, neonicotinoids and other risk factors PLOS ONE, 10(7): e0131611. doi:10.1371/journal.pone.0131611

van Engelsdorp, D., Evans, J. D., Saegerman, C., Mullin, C., Haubruge, E., Nguyen, B. K., ... Pettis, J. (2009). Colony Collapse Disorder: A descriptive study. PLOS ONE, 4(8): e6481. http://dx.doi.org/10.1371/journal. pone.0006481

Zhu, W., Schmehl, D. R., Mullin, C. A., \& Frazier, J.L. 
(2014). Four common pesticides, their mixtures and a formulation solvent in the hive environment have high oral toxicity to honey bee larvae. PLOS ONE, 9(1): e77547. doi: 10.1371/journal.pone.0077547 